Corresponding Author: Agni Laili Perdani; email:

agni.perdani@gmail.com

Published: 7 February 2022

Publishing services provided by Knowledge E

(c) Agni Laili Perdani et al. This article is distributed under the terms of the

Attribution License, which

permits unrestricted use and

redistribution provided that the original author and source are credited.

Selection and Peer-review under the responsibility of the IVCN Conference Committee.

\section{My Hero is You: Intervention to Reduce Anxiety and Depression in Children During the Covid-19 Pandemic in Indonesia}

\section{Agni Laili Perdani*, Triessa Riandani, and Dewi Srinatania}

Nursing, STIKep PPNI Jawa Barat

\section{ORCID}

Agni Laili Perdani: https://orcid.org/0000-0001-7105-1188

Abstract. The current Covid-19 pandemic has been very influential in all aspects of life, and not only adults but also children are victims. The prolonged school closures and social restrictions during this pandemic have had negative impacts on children's physical and mental health. The World Health Organization recommends storytelling to deal with psychological and mental health issues in children due to the Covid-19 pandemic. Storytelling helps children understand the current situation and gives them confidence that they can get through this difficult time. The purpose of this study was to determine how the storytelling method with the pomodoro technique can affect the psychological status of school-age children during the Covid-19 pandemic. This research was a quantitative study with a quasi-experimental, two groups, pre-test and post-test design. The research was conducted on 6-9 April 2021 at SD Negeri in Bandung, and 40 respondents were recruited using a simple random sampling technique. Data were collected using the $C D I$ and $C A Q$ questionnaires. The results of the study indicated that there was no significant difference in the level of depression $(p=0.277)$ or anxiety $(p=0.103)$ between the intervention group and control group. Storytelling with the pomodoro technique did not have a significant effect, even though it can reduce levels of depression and anxiety.

Keywords: storytelling, Covid-19, anxiety, depression, children

\section{Introduction}

The current situation of Covid-19 pandemic around the world is impacted all sectors of life including the school long closures [1]. It is important for children have access to education specifically in developing their social and cognitive. During unprecedented condition it can be dangerous for this vulnerable population and data reported there has been an increase in physical and emotional violence against children [2].

Children under age of 18 years represent about $8.5 \%$ of reported confirm cases Covid19 [3] and in Indonesia the total cases reached up to 5\% [1]. A study in Hong Kong and Brazil showed that children experienced anxiety, $14 \%$ and $19.4 \%$, consecutively while in Hubei, China, 22.6. \% of students experienced symptoms of depression and $18.9 \%$ 
The consequences of prolonged school closures and social restrictions by staying at home during pandemic have a negative effect on children physical and mental health. The symptoms including difficulty concentrating, mood changes, decrease in appetite, sleep disturbances and others [1]. These negative effects are likely to be much worse when children stay at home without outdoor activities and interactions with peers [5].

Children must have the opportunity to express fears and doubts [3]. It is important for children describe their experiences, anxiety, and perspectives during the Covid19 pandemic and understand their psychological experience [2]. Several important recommendations from WHO are released out for dealing with the psychological and mental health impacts among children. One of the intervention is storytelling.

Storytelling is the oldest form of teaching, with many benefits, including identifying emotional states, developing a vocabulary of feelings, and promoting resilience and hope [6]. In addition, storytelling is able to change child attention or distraction and reduce anxiety due to an illness [7]. Story telling with innovation by rest for 5-10 minutes before continuing the next lesson called Pomodoro technique [8]. This method increase learning motivation and maintain the flow of activities thus that they are not disturbed [9].

Previous study mentioned that the storytelling method can help children with HIVIAIDS reduce stress levels due to discrimination experienced by various media using fable, media online, videos, and comics. Storytelling can help children understand the current situation thus give them confidence that they can get through this difficult time [7]. Based on explanation above, researcher interest to study the effectiveness of storytelling method with the Pomodoro technique on the psychological status of school-age children during the Covid-19 pandemic.

\section{Method}

A quasi-experiment with pre-post test design with control and intervention group were implemented in this study. The total of 40 respondents agreed to involved in this study during period of Mei 2021 in one of the biggest elementary school at urban area, West Java, Indonesia.

Two questionnaire used in this study are Children's Depression Inventory (CDI) and Children's Anxiety Questionnaire (CAQ). CDI designed by measure depression symptoms in affection, cognitive and behavior among children age 7-17 years old with Likert Scale score from 0-3. CDI had reliability result with Cronbach's alpha 0.81 indicate good instrument. CAQ measure children anxiety by face emotion. Every express 
TABLE 1: General characteristics among school-age children in Indonesia ( $N=40)$

\begin{tabular}{|c|c|c|c|}
\hline Variables n(\%) & Intervention $(\mathrm{n}=\mathbf{2 0})$ & Control $(n=20)$ & p-value \\
\hline $\begin{array}{l}\text { Age (years old) Mean } \\
\pm \mathrm{SD} \leq 10 \quad 11 \geq 12 \\
\text { Grade } 456 \text { Gender } \\
\text { Male Female }\end{array}$ & $\begin{array}{l}11.25 \pm 0.853(3.25) 8 \\
(20) 9(22.5) 5(12.5) 6 \\
(15) 9(22.5) 12(30) 8 \\
(20)\end{array}$ & $\begin{array}{l}11.20 \pm 1.007(17.5) 3(7.5) \\
10(25) 4(10) 6(15) 10(25) \\
10(25) 10(25)\end{array}$ & $\begin{array}{ll}0.130 & 0.980 \\
0.068 & \end{array}$ \\
\hline
\end{tabular}

TABLE 2: Physiological status among school-age children in Indonesia ( $\mathrm{N}=40)$

\begin{tabular}{l|l|l|l|l|l|l} 
Variables & $\mathbf{t}$ & $\begin{array}{l}\text { Intervention } \\
\text { Mean } \pm \text { SD }\end{array}$ & $\begin{array}{l}\text { Control Mean 95\% Cl } \\
\pm \mathbf{S D}\end{array}$ & p-value \\
& & & & & & \\
\end{tabular}

emotion represent different score. In this study, data analyzed used SPSS Version 23 with univariate and bivariate formula (Independent T-test, Chi Square and ANCOVA).

The process of storytelling with Podomoro technique conducted in 2 days. Researcher read a lout a story through online media platform Google Meet with the title "My Hero Is You" developed by Helen Patuck for writing the story script and illustrating. This project is part from the Inter-Agency Standing Committee Reference Group on Mental Health and Psychosocial Support in Emergency Settings (IASC MHPSS RG). This project was supported by global, regional and country based experts in 104 countries.

\section{Results and Discussion}

\subsection{Demographic characteristics among school-age children}

Data showed that there is no statistically significant difference between intervention and control group in demographic characteristics (Table 1). The mean age in intervention

TABLE 3: The Effect of Storytelling Method with Pomodoro Technique

\begin{tabular}{|c|c|c|c|c|c|}
\hline Source & $\begin{array}{l}\text { Type III Sum of } \\
\text { Squares }\end{array}$ & df & $\begin{array}{l}\text { Mean } \\
\text { Square }\end{array}$ & $F$ & Sig. \\
\hline $\begin{array}{l}\text { Depression } \\
\text { Corrected Model } \\
\text { Intercept Pretest } \\
\text { Group Error Total }\end{array}$ & $\begin{array}{lr}61.378 & 13.682 \\
55.753 & 6.403 \\
119.597 & 895.000\end{array}$ & $\begin{array}{lll}2 & 1 & 1 \\
37 & 40\end{array}$ & $\begin{array}{l}30.689 \\
13.682 \\
55.753 \\
6.4033 .232\end{array}$ & $\begin{array}{l}9.494 \\
4.233 \\
17.248 \\
1.981\end{array}$ & $\begin{array}{l}0.000^{* *} \\
0.047 \\
0.000^{* *} \\
0.168\end{array}$ \\
\hline $\begin{array}{lr}\text { Anxiety } & \text { Corrected } \\
\text { Model } & \text { Intercept } \\
\text { Pretest } & \text { Group Error } \\
\text { Total } & \end{array}$ & $\begin{array}{lr}36.696 & \\
2.806 & 31.071 \\
4.635 & 45.279 \\
1657.000 & \end{array}$ & $\begin{array}{lll}2 & 1 & 1 \\
37 & 40\end{array}$ & $\begin{array}{l}18.348 \\
2.80631 .071 \\
4.6351 .224\end{array}$ & $\begin{array}{l}14.993 \\
2.293 \\
25.390 \\
3.788\end{array}$ & $\begin{array}{l}0.000^{* *} \\
0.138 \\
0.000^{* *} \\
0.059\end{array}$ \\
\hline
\end{tabular}


group is $11.25(S D \pm 0.85)$ while in control $11.20(S D \pm 1.00)$. Most respondents aged $\geq 12$ years old, on grade 6 and male (Table 1).

The worldwide prevalence of any anxiety disorder among children according to the Diagnostic and Statistical Manual (DSM) and the International Statistical Classification of Diseases and Associated Health Problems (ICD) has been shown to be 6.5\% in children aged 11-12 years [2]. This is in line with the research of [10]. who found that younger children seemed more free to express themselves and their thoughts, whereas older children felt embarrassed if they had to express themselves and their own feelings which made them appear less confident. According to [11] the age of 9-12 years has the development of an individualistic attitude which is an advanced stage from the age of 6-9 years, at this stage students increasingly want to know themselves by comparing themselves with peers. Without guidance, children tend to find it difficult to adapt, especially to the current Covid-19 pandemic conditions, children's very limited social activities affect the child's development period.

Girls are generally more adaptive in dealing with stressors than boys, so girls experience less depression and anxiety than boys [12]. In the study of [13] revealed that during the Covid-19 pandemic over time compared to boys, girls had higher emotional symptoms and lower symptoms of inattention, but girls had higher levels of problems. lower behavior because they have better adaptability than boys. However, in the study of [13] showed that there was no significant interaction between gender and the psychological status of children.

Respondents in this study were students in grades 4, 5, and 6 which were high grade students. In the research [14] depression and anxiety occur throughout childhood differently, studies show that older children exhibit more depressive symptoms than younger children. Researchers found that depression and anxiety were mostly experienced by age 12 years and were in the 6th grade of elementary school education. According to [11] the current pandemic condition that requires students to adapt to studying at home creates its own pressure on students. Academic stress is stress that arises due to pressure to show achievement and excellence in academic competition, so that students feel burdened by various demands.

Academic stress occurs due to a mismatch between environmental demands and the actual resources currently owned by students. In the Big Class elementary school students, students are in the pre-adolescent stage of development, the stage where children find it difficult to build communication relationships between children and parents. Meanwhile, at this time, students must learn from home and lead children to build more communication with parents. This includes social stressors related to 
interactions or interpersonal relationships at school such as interacting with teachers, peers. Grade 6 is the final level of elementary school which is then continued at the junior high school level, with the current pandemic conditions causing academic stress, children will be more worried about their future.

Based on research by [1] children's reactions after a traumatic event will vary depending on their age, developmental level, level of social support, and problem-solving skills. So it can be concluded that there are many factors other than age that can affect psychological status, such as the level of development, social environment, information that is not understood by children, parental attention needed by children, and so on.

\subsection{Anxiety and depression level among school-age children}

From bivariate analysis showed that in variables anxiety and depression among two group there were no significant mean difference (Table 2). However, there is decreased on total mean score after story telling conducted in intervention group. At depression status the mean score before was $5.50\left(\mathrm{SD}_{ \pm 2} .60\right)$ with $\mathrm{t}\left({ }_{40}\right)=-1.104$ and after is $3.85(\mathrm{SD} \pm 1.66)$ with the value of $\left.\mathrm{t}_{40}\right)=0.13$. For anxiety level the average score before was $6.95(\mathrm{SD} \pm 1.43)$ with $\left.\mathrm{t}_{40}\right)=-0.24$ and after is $5.90(\mathrm{SD} \pm 1.29)$ with $\left.\mathrm{t}_{40}\right)=-1.673$ and clearly there was a change after the intervention was given.

Based on the results of the analysis of table 4.2 the difference in psychological status after being given the storytelling method with modification of the pomodoro technique in the intervention group and health education without storytelling in the control group showed insignificant results, the difference in depression status between the intervention and control groups had a p-value of 0.277 (> 0.05 ), while the anxiety status has a p-value of 0.103 (>0.05).

However, the changes in the level of depression and anxiety after the intervention can be seen from the mean or average score. Both groups showed mild depression and low anxiety, in the intervention group the previous depression status was 5.50 after being given storytelling with pomodoro to 3.85 , while the previous anxiety status was 6.95 to 5.90. In the control group the mean score of depression status was 6.40 and after that it was 4.60 , and the previous anxiety status was 7.50 to 6.65 . Both groups experienced a decrease in the average score, this proves that the storytelling method with the pomodoro technique does not have a significant effect between the intervention and control groups, but can still reduce depression and anxiety status of school-age children. 
According to UNICEF, children may find it difficult to understand what they see in online news or on television, and they are vulnerable to anxiety, stress and grief. Guidelines on 'How to talk to children about Covid-19?' It is recommended that parents or guardians ask their children open-ended questions, and ensure that the child listens to the answers. In addition, use language that is appropriate for the child's age, pay attention to reactions, and show sensitivity to their level of anxiety, and close conversations carefully [2]

Storytelling with the pomodoro technique is one of the therapeutic play techniques in conveying an idea, the content of feelings by dividing the time so that the brain can more easily understand the information provided. Giving storytelling treatment is able to reduce levels of depression and anxiety [12]. Storytelling leads to the mental and emotional health of children. Many studies have been conducted on the importance of storytelling for children and have been shown to have a significant influence on children's mental development [15].

Currently, there are not many methods used and researched to overcome the psychological problems of children due to the Covid-19 pandemic, according to [16] there are reports showing that children are at risk of increased anxiety during the Covid-19 pandemic, researchers reveal that Online video games can provide positive benefits for reducing anxiety levels during lockdown and are safe or not causing behavioral and emotional control, but online video games also have a negative effect, namely addiction if the time used is not optimal. It is different with storytelling which can develop children's language and emotional skills, accompanied by time management techniques to optimize children's thinking processes.

The absence of significant changes in psychological status between the intervention and control groups could be caused by various factors such as school, extracurricular activities, social interaction, and physical activity. In the case of the Covid-19 pandemic, children's mental health is strongly influenced by the family system and family interactions. The existence of a prolonged lockdown has resulted in families experiencing difficult times both financially, making families have to work extra to meet their daily needs, the impact of which is the quality of togetherness of family members is reduced, this makes the family environment a major risk factor for children's mental health [17]. This is in line with research by Ravens-[18] who revealed that children with low socioeconomic status and pre-existing mental health problems may be exposed to cumulative risk. This assumption is based on previous research showing that low socioeconomic status, low parental education level, and family migration status are risk factors for mental health problems among children. 


\subsection{The effect of storytelling toward Anxiety and depression level among school-age children}

Based on the ANCOVA analysis in Table 3 above, there is an effect of storytelling toward anxiety and depression $(p<0.005)$.It can be concluded that the storytelling method with Podomor technique had an effect on the level of depression and anxiety, but there was no significant difference between the intervention and control groups.

Changes in depression status in both groups using the CDI instrument have a significant value on statement number 3 which contains: "I do most things well"; "I did some things wrong"; and "I did everything wrong" p-value of $0.036(<0.05)$, indicating that school-age children in the intervention and control groups had significant changes in statement number 3. Meanwhile, in the anxiety status, there was no significant change between the four statements using the CAQ instrument. Each statement used in this research instrument describes and explains how the child feels during the Covid-19 pandemic and also knows what factors influence the child's feelings. Expectations about pandemics can adversely affect children's mental health in several ways, pessimistic perspectives on pandemics such as the fear of being infected or having an infected relative [14].

Adaptation to new situations such as the current Covid-19 pandemic can lead to various new demands and pressures on school-age children, considering that the development of school-age children tends to use social comparisons, especially social norms and certain behaviors that make children feel unable to do some things. big things well than their peers. Feelings of helplessness can lead to emotional problems [11]. Giving storytelling using the pomodoro technique about Covid-19 helps children understand what to do in dealing with Covid-19, the story entitled "You are my Pahlwanaku" recommended by WHO in this study tells that every child can become a hero by doing activities in accordance with health protocols, maintaining distance, and staying at home to prevent the transmission of Covid-19 for himself, his family and those around him. This fosters the child's feeling that they are capable of doing things well just like their peers. So that the influence of the storytelling method with the pomodoro technique is evidenced by a change in depression status using the CDI instrument in statement number 3.

Based on the analysis of demographic data on depression and anxiety status, showing mild depression status and low anxiety status, this could be one of the factors that resulted in no significant difference between the intervention and control groups, even though the intervention given had an effect on decreasing depression and anxiety 
scores. In the study of [2] revealed that children who stay at home with their father and mother have lower CAQ scores than those who are separated from their parents. This finding confirms the important role of parents in children's lives, especially during a pandemic. In addition, there are many articles on the importance of physical activity during the lockdown. Regular physical exercise with parents related to cases of depression and anxiety is considered the second most effective measure to reduce the psychological burden on children, especially at the age of 3-18 years [19].

The most important thing for children is to have adults around them, children feel better when they can communicate their feelings in a supportive environment. Adults need to be honest about the uncertainties and challenges during a pandemic without burdening children with fear [2]. Storytelling is one of the secondary educational and therapeutic applications. Story therapy can be used in cognitive behavioral therapy for children, stories can be considered as an important source of change and improvement, creating a context for children's release and imitation, and raising perceptions [15]. Stories like "My Hero Is You" can provide information and opportunities for children to release their emotions and feelings in the face of the Covid-19 pandemic.

\section{Conclusion}

The storytelling method with the modification of the pomodoro technique can be done by teachers on the sidelines of giving lessons, so that students still get attention, especially regarding psychology during the Covid-19 pandemic. Teachers or teaching staff can provide contextual learning in accordance with student learning conditions at home. The storytelling method with the pomodoro technique can be applied when providing health education about Covid-19 by teachers or health staff.

\section{References}

[1] Meutia A. Dampak pandemi covid 19 pada psikis dan ingatan aank. Elementary School Journal Pgsd Fip Unimed. 2020;10(1):60-66.

[2] Garcia de Avila MA, Hamamoto Filho PT, Jacob FS, et al. Children's anxiety and factors related to the COVID-19 pandemic: An exploratory study using the children's anxiety questionnaire and the numerical rating scale. International Journal of Environmental Research and Public Health. 2020;17(16):5757.

[3] World Health Organization. Children's story book released ro help children and young people cope with Covid-19. WHO; 2020 Sept 4. Available 
from: https://www.who.int/news/item/09-04-2020-children-s-story-book-released-tohelp-children-and-young-people-cope-with-covid-19

[4] Xie X, Xue Q, Zhou Y, et al. Mental health status among children in home confinement during the coronavirus disease 2019 outbreak in Hubei Province, China. JAMA Pediatrics. 2020;174(9):898-900.

[5] Wang G, Zhang Y, Zhao J, Zhang J, Jiang F. Mitigate the effects of home confinement on children during the COVID-19 outbreak. The Lancet. 2020;395(10228):945-947.

[6] Sullivan MA, Paccione-Dyszlewski M. Consider storytelling to help children cope during COVID-19. The Brown University Child and Adolescent Behavior Letter. 2020;36(11):8-8.

[7] Darmawan TC. Kombinasi metode story telling dan terapi musik dalam upaya menurunkan stress pada aanak dengan HIVIAIDS di wilayah surabaya. Journals of Ners Community. 2020;11(2):148-157.

[8] Cirillo F. The pomodoro technique. California: Creative Commons; 2007.

[9] Malureanu F, Enachi-Vasluianu L. Teaching strategies of learning.

[10] Aisha I, Kaloeti DVS. Digital storytelling intervention on prosocial behavior improvement among early childhood. Psympathic: Jurnal IImiah Psikologi. 2020;7(2):185-196.

[11] Palupi TN. Tingkat stres pada siswa-siswi sekolah dasar dalam menjalankan proses belajar di rumah selama pandemi covid-19. Jurnal Psikologi Pendidikan dan Pengembangan Sdm. 2020;9(2):18-29.

[12] Padila P, Agusramon A, Yera Y. Terapi story telling dan menonton animasi kartun terhadap ansietas. Journal of Telenursing ( JOTING). 2019;1(1):51-66.

[13] Waite P, Pearcey S, Shum A, Raw J, Patalay P, Creswell C. How did the mental health of children and adolescents change during early lockdown during the COVID-19 pandemic in the UK?. 2020.

[14] de Miranda DM, da Silva AB, de Sena OAC, Silva ACS. How is COVID-19 pandemic impacting mental health of children and adolescents? International Journal of Disaster Risk Reduction. 2020;101845.

[15] Ghasemian K, Estahbanati MAE. The effectiveness of storytelling on reducing depression in cancer patients. Humanidades \& Inovação. 2019;6(9):278-284.

[16] De Pasquale C, Chiappedi M, Sciacca F, Martinelli V, Hichy Z. Online videogames use and anxiety in children during the COVID-19 pandemic. Children. 2021;8(3):205.

[17] Courtney D, Watson P, Battaglia M, Mulsant BH, Szatmari P. COVID-19 impacts on child and youth anxiety and depression: challenges and opportunities. The Canadian Journal of Psychiatry. 2020;65(10), 688-691. 
[18] Ravens-Sieberer U, Kaman A, Erhart M, Devine J, Schlack R, Otto C. Impact of the COVID-19 pandemic on quality of life and mental health in children and adolescents in Germany. European Child \& Adolescent Psychiatry. 2021:1-11.

[19] Yusuf NR. Assessing self-rated instruments to detect suicidal thought among high school students in Jakarta. KnE Life Sciences. 2018:415-421. 